\title{
Abiotic U(VI) reduction by aqueous sulfide
}

\author{
Sung Pil Hyun, ${ }^{1,2, *}$ James A. Davis, ${ }^{3}$ Kim F. Hayes ${ }^{1}$ \\ ${ }^{1}$ Department of Civil and Environmental Engineering, University of Michigan; \\ ${ }^{2}$ Groundwater Department, Korea Institute of Geoscience and Mineral Resources; \\ ${ }^{3}$ Earth Sciences Division, Lawrence Berkeley National Laboratory
}

\section{Abstract}

Reactions with aqueous sulfide are important in determining uranium (U) geochemistry under sulfate reducing conditions. This paper reports on abiotic reduction of U(VI) by aqueous sulfide under a range of experimental conditions using batch reactors. Dissolved U concentration was measured as a function of time to study the effects of chemical variables including $\mathrm{pH}, \mathrm{U}(\mathrm{VI}), \mathrm{S}(-\mathrm{II})$, total dissolved carbonate $\left(\mathrm{CARB}=\mathrm{H}_{2} \mathrm{CO}_{3}{ }^{*}+\mathrm{HCO}_{3}{ }^{-}+\mathrm{CO}_{3}{ }^{2-}\right)$, and $\mathrm{Ca}^{2+}$ concentration on the $\mathrm{U}(\mathrm{VI})$ reduction rate. Solid phase reaction products were characterized using X-ray diffraction, X-ray absorption spectroscopy, and transmission electron microscopy. The chemical variables had impacts on the solid phase U(VI) reaction products as well as the reduction rates by aqueous sulfide. The solid $\mathrm{U}$ reaction product at circumneutral $\mathrm{pH}$ was identified as uraninite $\left(\mathrm{UO}_{2+\mathrm{x}(\mathrm{s})}\right)$. Under basic $\mathrm{pH}$ conditions, whether a precipitate occurred depended on $\mathrm{Ca}^{2+}$ and $\mathrm{CARB}$ concentrations. U(VI) reduction was faster under higher S(-II) concentrations but was slowed by increased dissolved $\mathrm{Ca}^{2+}$ or $\mathrm{CARB}$ concentration. In the

\footnotetext{
${ }^{*}$ Corresponding author: Sung Pil Hyun

Current address: Korea Institute of Geoscience and Mineral Resources

124 Gwahang-no, Yuseong-gu

Daejeon 305-350, Korea

Tel) +82-42-868-3315, Fax) +82-42-868-3414

E-mail) sphyun@kigam.re.kr

E-mail addresses: sphyun@kigam.re.kr (S.P. Hyun), jadavis@lbl.gov (J.A. Davis), ford@umich.edu (K.F. Hayes)
}

Page $1 / 42$ 
1 absence of dissolved CARB and $\mathrm{Ca}^{2+}$, a rapid decrease in dissolved $\mathrm{U}$ concentration occurred at

2 circumneutral $\mathrm{pH}$, while virtually no decrease was observed at $\mathrm{pH} 10.7$ within the experimental

3 timeframe of two days. The $\mathrm{U}(\mathrm{VI})$ reduction rate was proportional to the total concentration of

4 free uranyl plus its hydrolysis complexes even at minor to trace concentrations. Dissolved $\mathrm{Ca}^{2+}$

5 and CARB slow abiotic $\mathrm{U}(\mathrm{VI})$ reduction by forming stable $\mathrm{Ca}-\mathrm{U}(\mathrm{VI})$-carbonato soluble

6 complexes that are resistant to reaction with aqueous sulfide. U(VI) reduction was slow in a

7 synthetic solution representative of groundwater at a uranium mill tailings site. This study

8 illustrates that abiotic $\mathrm{U}$ reduction by aqueous sulfide can significantly vary under typical ranges

9 of chemical conditions in groundwater and newly demonstrates the importance of dissolved $\mathrm{Ca}^{2+}$

10 in the abiotic $\mathrm{U}(\mathrm{VI})$ reduction by aqueous sulfide. The results contribute to our understanding of

11 the impact of sulfate reducing conditions on $\mathrm{U}$ speciation in groundwater systems undergoing

12 bioreduction conversion of $\mathrm{U}(\mathrm{VI})$ to less mobile $\mathrm{U}(\mathrm{IV})$ solid phases.

13 Keywords: uranium(VI); abiotic reduction; aqueous sulfide; $\mathrm{Ca}^{2+}$; carbonate

\section{Introduction}

Redox chemistry of uranium $(\mathrm{U})$ needs to be considered in reactive transport models that

17 are used for long-term assessment of $\mathrm{U}$ migration in contaminated aquifers. Under sufficiently

18 reducing conditions, the more mobile $\mathrm{U}(\mathrm{VI})$ in the form of dissolved uranyl ion species can be

19 reduced to less mobile U(IV) solid phase species. To facilitate this transformation, injection of a

20 carbon source into contaminated groundwaters has been used to stimulate iron or sulfate

21 reducing conditions (Anderson et al., 2003; Qafoku et al., 2009; Moon et al., 2010). Under

22 sulfate reducing conditions, microbiological and chemical reduction of $U$ may occur

23 simultaneously (Boonchayaanat et al, 2010; Hua et al., 2006; Lovley and Phillips, 1992),

24 complicating the assessment of each contribution. For example, sulfate reducing 
1 microorganisms have been shown to directly reduce $\mathrm{U}(\mathrm{VI})$ to $\mathrm{U}(\mathrm{IV})$ as part of their metabolic

2 processes (Lovley and Phillips, 1992; Lovley et al., 1993; Pietzsch et al., 1999). Alternatively,

3 the sulfide produced by microbial activity under natural or stimulated sulfate reducing conditions

4 at $\mathrm{U}$ contaminated sites may subsequently react with U(VI) and reduce it to U(IV) or react with

5 iron to form ferrous sulfide precipitates that may reduce U(VI) to U(IV) (Hua et al., 2006; Hua

6 and Deng, 2008; Hyun et al., 2012).

7 The research presented here focuses on the chemical reactions responsible for abiotic $\mathrm{U}$

8 redox transformations under sulfate reducing conditions. Field-scale biostimulation experiments

9 have been carried out at a DOE U-contaminated site (U mill tailings site in Rifle, CO) by

10 intermittently injecting acetate into the shallow aquifer and monitoring groundwater chemistry

11 and microbial community changes (Yabusaki et al., 2007). The results have shown that iron

12 reducing bacteria effectively immobilized $U$ (Anderson et al., 2003). However, once the terminal

13 electron acceptor, Fe(III), was effectively depleted, sulfate reduction became predominant, but

14 acetate-oxidizing sulfate-reducing bacteria appeared to be not as effective at U(VI)

15 immobilization (Anderson et al., 2003; Lovley et al., 1993; Williams et al., 2011). A recent in

16 situ column study has shown that $\mathrm{U}$ immobilization under sulfate reducing conditions occurs

17 mainly by U reduction to "molecular" U(IV) species (Bernier-Latmani et al., 2010). Yet, the

18 relative contributions that are due to biotic or abiotic processes are still not clear. A better

19 understanding of $\mathrm{U}$ redox transformations under sulfate reducing conditions therefore requires

20 isolating the chemical processes from microbial metabolic $U$ redox processes, and, in particular,

21 the role of aqueous sulfide as a reducing agent over a range of environmentally relevant

22 conditions. 
Abiotic reduction of $U$ has been reported by Fe(II) oxyhydroxide minerals (O'Loughlin et

2 al., 2003; Rosenspurg et al., 2009), Fe(II) sulfide minerals (Wersin et al., 1994; Moyes et al., 2000; Livens et al., 2004), adsorbed Fe(II) (Chakraborty et al., 2010; Jeon et al., 2005; Liger et al., 1999; Fox et al., 2013), and aqueous sulfide (Hua et al., 2006). Recent papers suggest that slight changes in U(VI) aqueous speciation may affect the thermodynamic feasibility of abiotic $\mathrm{U}(\mathrm{VI})$ reduction, noting the closeness of redox couples $\mathrm{U}(\mathrm{IV}) / \mathrm{U}(\mathrm{VI}), \mathrm{Fe}(\mathrm{II}) / \mathrm{Fe}(\mathrm{III})$ oxides, and $\mathrm{HS}^{-} / \mathrm{SO}_{4}{ }^{2-}$ (Ginder-Vogel et al., 2006; Borch et al., 2010). These conclusions were originally made in the context of uraninite oxidation, but the same reasoning should apply for U(VI) reduction. It follows that chemical variables such as $\mathrm{pH}$, carbonate, and calcium, which change $\mathrm{U}(\mathrm{VI})$ speciation, may have impacts on $\mathrm{U}(\mathrm{VI})$ reduction . Under sulfate reducing conditions, it is thus of practical importance to assess the feasibility of U(VI) reduction by aqueous sulfide under variable chemical conditions.

In this study, abiotic $\mathrm{U}(\mathrm{VI})$ reaction with aqueous sulfide was investigated over a range of chemical conditions, including U(VI), S(-II), total dissolved carbonate (hereafter CARB, equals $\mathrm{H}_{2} \mathrm{CO}_{3}{ }^{*}+\mathrm{HCO}_{3}{ }^{-}+\mathrm{CO}_{3}{ }^{2-}$ ), and $\mathrm{Ca}^{2+}$ concentrations under circum-neutral $\mathrm{pH}$ conditions ( $\mathrm{pH}$ 6.7, 7.1, and 7.3). The research questions addressed were: 1) what are the U(VI) reaction products with aqueous sulfide over a range of environmentally relevant conditions?; and 2) what conditions promote abiotic $\mathrm{U}(\mathrm{VI})$ reduction by aqueous sulfide? Related to the first questions, previous studies report different reaction products from aqueous sulfide reduction of U(VI), depending on experimental conditions. For example, several have reported a partially reduced mixed-valent U solid phase forms (Wersin et al., 1994; Moyes et al., 2000; Livens et al., 2004), while others found uraninite precipitation when U(VI) was reacted with ferrous sulfide or aqueous sulfide in Ca-free systems (Hua et al., 2006; Hua and Deng, 2008). In more recent 
1 investigations, "molecular" U(IV) species formed as a reaction product, contrary to the long-held

2 belief that U(IV) quickly forms extremely insoluble reduced U solid phases (Bernier-Latmani et

3 al., 2010; Fletcher et al., 2010; Sivawamy et al., 2011). Regarding the second question, Hua et

4 al. (2006) reported that the $\mathrm{U}$ reduction rate by aqueous sulfide was proportional to the sum of

5 the $\mathrm{U}(\mathrm{VI})$-hydroxide species concentrations, suggesting a strong influence of $\mathrm{U}(\mathrm{VI})$ aqueous

6 speciation on the reduction rate. However, these authors used $\mathrm{pH}$ buffers (12.5mM PIPES and

7 TRIS), and very high dissolved carbonate concentrations (up to $30 \mathrm{mM}$ ), and $\mathrm{Ca}^{2+}$ was absent in

8 their experiments. These results may not be directly applicable to natural systems. The work

9 presented here includes a wider range of chemical conditions, and concentrations more 10 representative of natural and $\mathrm{U}$ contaminated groundwater sites.

\section{Materials and Methods}

\subsection{Batch $U(\mathrm{VI})$ reaction with aqueous sulfide.}

Batch reactor reduction experiments were performed under $\mathrm{N}_{2}$ atmosphere (with $4 \% \mathrm{H}_{2}$

17 (18.3 M $\Omega-\mathrm{cm})$ inside the anaerobic chamber. All the glassware and plastic bottles were stored in

18 the anaerobic chamber at least 2 days before use to ensure that $\mathrm{O}_{2}$ molecules possibly adsorbed to the vessel walls were exchanged and removed under the $\mathrm{N}_{2}$ atmosphere. Abiotic reactions of aqueous $\mathrm{U}(\mathrm{VI})$ with aqueous sulfide were carried out in $150 \mathrm{~mL}$ batch reactors in the anaerobic

21 chamber, following Beyenal's method (Beyenal et al., 2004). In the simplest aqueous phase

22 system, a $180 \mu \mathrm{M}$ uranyl nitrate solution (as $\mathrm{U}(\mathrm{VI})$ ) was reacted with $1 \mathrm{mM}$ sodium sulfide

23 solution (as $\mathrm{S}(-\mathrm{II})$ ) without $\mathrm{CARB}$ and $\mathrm{Ca}^{2+}$. In a second experiment, $\mathrm{Ca}^{2+}$ and $\mathrm{CARB}$ were 
1 added to the sulfide solution ( $1 \mathrm{mM} \mathrm{S}, 1 \mathrm{mM} \mathrm{CARB}$, and $5 \mathrm{mM} \mathrm{Ca}^{2+}$ ) and reacted with the $180 \mu \mathrm{M}$

2 uranyl nitrate solution to get a preliminary assessment of their impact on U(VI) reduction by

3 sulfide. After this, $\mathrm{U}(\mathrm{VI})$ was reacted with $10 \mathrm{~mL}$ solution of sulfide in $15 \mathrm{~mL}$ polypropylene

4 conical tubes in solutions containing various other specific concentrations of $\mathrm{CARB}$ and $\mathrm{Ca}^{2+}$ to

5 see the trends of changes in $\mathrm{U}$ speciation and reduction. The desired reaction $\mathrm{pH}$ was obtained

6 by adding appropriate amounts of hydrochloric acid. No $\mathrm{pH}$ buffer was used, but the $\mathrm{pH}$ was

7 well buffered in the presence of CARB. During the course of reaction, the batch reactor tubes

8 were continuously mixed on an end-over-end rotator (60rpm). At each time point, the final

9 solution $\mathrm{pH}$ in the reactor tube was measured and then the solution was filtered with a $0.1 \mu \mathrm{m}$

10 nylon syringe filter (GE Cameo) using a lubricant-free plastic disposable syringe (National

11 Scientific). Dissolved U in the solution was measured by inductively coupled plasma mass

12 spectrometry (Perkin-Elmer Elan). Chemical conditions were systematically varied to test the

13 effect of each variable on $\mathrm{U}(\mathrm{VI})$ reduction rates. The experimental ranges were chosen to

14 encompass the conditions observed for Rifle groundwater (Hyun et al., 2009), where the field-

15 scale biostimulation experiments were run (Yabusaki et al., 2007). Initial U(VI) concentration

16 ranged between $3.5 \times 10^{-7}$ and $10^{-4} \mathrm{M}$, dissolved sulfide between 1 and $10 \mathrm{mM}$, CARB between 1

17 and $5 \mathrm{mM}$, and $\mathrm{Ca}^{2+}$ between 0 and $5 \mathrm{mM}$. The synthetic solution used to simulate the Rifle

18 aquifer groundwater contained $\left[\mathrm{Na}^{+}\right]=10 \mathrm{mM},\left[\mathrm{K}^{+}\right]=0.4 \mathrm{mM},\left[\mathrm{Mg}^{2+}\right]=4 \mathrm{mM},\left[\mathrm{Ca}^{2+}\right]=4.8 \mathrm{mM}$,

19 CARB $=7.7 \mathrm{mM},\left[\mathrm{Cl}^{-}\right]=3 \mathrm{mM},\left[\mathrm{SO}_{4}{ }^{2-}\right]=8.8 \mathrm{mM}$, and $\mathrm{pH}=7$. Three different initial $\mathrm{U}$

20 concentrations $\left(4 \times 10^{-7}, 4 \times 10^{-6}\right.$, and $\left.4 \times 10^{-5} \mathrm{M}\right)$ were used for the experiments using synthetic

21 groundwater. Equilibrium aqueous $\mathrm{U}(\mathrm{VI})$ speciation was calculated using Visual MINTEQ

22 (ver.3.0). The NEA database (Guillaumont et al., 2003) was used for $\mathrm{U}$ species, with $\mathrm{Ca}_{\mathrm{x}}-\mathrm{UO}_{2^{-}}$ 
$1 \mathrm{CO}_{3}$ species from Dong and Brooks (2006), consistent with our previous work (Hyun et al., 2 2009).

$4 \quad$ 2.2. Solid Phase Characterization.

Solid phase reaction products were characterized using X-ray diffraction (University of

6 Michigan X-ray Microbeam Analysis Laboratory), transmission electron microscopy (University

7 of Michigan Electron Microbeam Analysis Laboratory), and X-ray absorption spectroscopy

8 (Stanford Synchrotron Radiation Lightsource). U $L_{\mathrm{III}}$ edge X-ray absorption spectroscopy data

9 were collected at the Stanford Synchrotron Radiation Lightsource (SSRL). XAS samples were

10 prepared under the same experimental conditions as the batch kinetic experiments, but scaled up

11 to collect enough amounts of samples necessary for the XAS data collection. Fluorescence X-ray

12 absorption data were measured at the beam lines 11-2 and 4-1 using a 30- or 13-element Ge

13 detector or Lytle detector. The beam energy was calibrated by setting the simultaneously

14 measured $K$ edge position of a $\mathrm{Y}$ foil as $17038 \mathrm{eV}$. To improve the signal-to-noise ratio, multiple

15 scans were measured using a liquid nitrogen cryostat. To minimize the higher order harmonics,

16 the monochromator crystals were detuned $30 \%$. The data were collected at $3 \mathrm{GeV}$ with beam

17 current of 200-195 mA. A Sr-3 or Sr-6 filter was used as necessary depending on the florescence

18 signal quality. EXAFS data reduction and model based fitting analyses were performed using

19 SixPack (Webb, 2002). Feff8.10 code was used to calculate phase-shift and amplitude functions

20 for U-backscatterer pair scattering paths (Ankudinov et al., 2002). The crystallographic input

21 files for Feff calculation were generated using ATOMS (Ravel, 2001). The background removed,

22 averaged EXAFS spectra were converted from energy space to the photoelectron wave vector $k$

23 space. The fitting was performed using the Feff EXAFS fitting module typically in the range of 
$13<k<12$. The accuracy of the bond length and coordination number was estimated to be $\pm 0.02 \AA$

2 and $24 \%$ for the first shell, respectively. To obtain the best fitting results, the Debye-Waller

3 factor $\left(\sigma^{2}\right)$ and energy reference $E_{0}$ were floated in the fitting process, whereas the many-body

4 factor $\left(S_{0}{ }^{2}\right)$ was fixed at 0.9 . The $R$ factor of SixPack was used as the goodness of EXAFS fitting

5 to the measured data in comparing different combination of structural parameters (Webb, 2002).

\section{Results}

Dissolved U concentration as a function of time in the simplest model system (1mM S(-

9 II), no $\mathrm{CARB}$, no $\mathrm{Ca}^{2+}$ ) is given in Figure 1. The equilibrium $\mathrm{pH}$ was stable at 10.7 without time. However, when the $\mathrm{pH}$ was titrated down to 7 by adding $1 \mathrm{~N}$ nitric acid, the dissolved $\mathrm{U}$

12 concentration immediately decreased to below detection limit (Fig. 1) with the appearance of a 13 dark precipitate. In systems amended with $1 \mathrm{mM} \mathrm{CARB}$ and $5 \mathrm{mM} \mathrm{Ca}^{2+}$ (at $1 \mathrm{mM}$ total sulfide), 14 the dissolved U(VI) concentration decreased as a function of reaction time under both 15 circumneutral and basic $\mathrm{pH}$ conditions (Data not shown). However, the resulting precipitates 16 were different under circumneutral and basic $\mathrm{pH}$ conditions. The precipitate formed at 17 circumneutral $\mathrm{pH}$ had a dark color similar to the precipitate formed in the absence of $\mathrm{Ca}^{2+}$ and 18 CARB. However, the precipitate formed at $\mathrm{pH} 10.7$ had a distinctly different yellow color. 19 Further characterization results at circumneutral $\mathrm{pH}$ are discussed in the following section.

\section{$21 \quad$ 3.1.Solid Phase Reaction Products.}

3.1.1. $\mathrm{Ca}^{2+}$ - and $C A R B$-free Model System. The solid phase reaction products in the 23 reaction of $\mathrm{U}(\mathrm{VI})$ with aqueous sulfide were characterized using X-ray diffraction (XRD), 
1 transmission electron microscopy (TEM), and X-ray absorption spectroscopy (XAS). The

2 results for the precipitate formed at $\mathrm{pH} 7$ in the $\mathrm{Ca}^{2+}$ - and $\mathrm{CARB}$-free system are illustrated in

3 Figure 2. Both XRD (Fig. 2a) and selected area electron diffraction (Fig. 2c) confirmed that the

4 precipitate formed by the homogeneous reaction of dissolved U(VI) and aqueous sulfide was

5 uraninite under circum-neutral $\mathrm{pH}$ in this simple system with only dissolved U(VI), sulfide,

6 nitrate, sodium, $\mathrm{H}^{+}$, and $\mathrm{OH}^{-}$in anoxic water. $\mathrm{XAS}$, which gives an independent set of

7 information regarding the local coordination structure of $U$, confirms the formation of uraninite

8 by $\mathrm{U}(\mathrm{VI})$ reaction with aqueous sulfide in the $\mathrm{Ca}^{2+}$ - and CARB-free system (Fig. 2d and e).

9 XANES (Fig. 2d) shows that the edge position of the $U L_{\mathrm{III}}$-edge X-ray absorption spectrum

10 shifted to $17172 \mathrm{eV}, c a .2 \mathrm{eV}$ lower than the starting $\mathrm{U}(\mathrm{VI})$ solution, indicating $\mathrm{U}$ reduction to

$11 \mathrm{U}(\mathrm{IV})$. EXAFS analysis (Fig. 2e) gives structural parameters of 6.1 nearest oxygen neighbors at

12 the interatomic distance of $2.26 \AA$ from the central $U$ atom and of 3.6 second shell uranium

13 neighbors at $3.83 \AA$. These structural parameters are consistent with the reported structure of

14 uraninite, although the coordination number for the uranium shell is lower than that expected for

15 a well crystalline uraninite (Wyckoff, 1978; Schofield et al., 2008). Similar observation of low

16 coordination number for the nearest $\mathrm{U}$ atoms is reported to be due to the nanocrystalline nature

17 of the uraninite precipitate in a study of $\mathrm{U}(\mathrm{VI})$ reaction with green rust or mackinawite

18 (O’Loughlin et al., 2003). The following 1:1 stoichiometric relation between U(VI) and S(-II) is

19 suggested from a previous study of U(VI) reduction by dissolved sulfide under similar

20 experimental conditions (Hua et al., 2006):

21

$$
\mathrm{UO}_{2}^{2+}+\mathrm{HS}^{-} \rightarrow \mathrm{UO}_{2(\mathrm{~s})}+\mathrm{S}_{(\mathrm{s})}^{0}+\mathrm{H}^{+}
$$

22 Considering the aqueous speciation of $\mathrm{U}(\mathrm{VI})$, the following are the reactions for the predominant $23 \mathrm{U}(\mathrm{VI})$ species: 
1

2

3 Characterization of the solid phase reaction product confirms that in the absence of $\mathrm{Ca}^{2+}$ and

4 CARB, U(VI) is reduced to uraninite under the circum-neutral $\mathrm{pH}$ by reaction with aqueous

5 sulfide, but U(VI) remains as dissolved U(VI) without formation of any solid phase under the

6 basic $\mathrm{pH}$ condition.

7

8

9

10

11

12

13

14

15

16

17

18

19

20

21

22

$$
\left(\mathrm{UO}_{2}\right)_{4}(\mathrm{OH})_{7}{ }^{+}+4 \mathrm{HS}^{-} \rightarrow 4 \mathrm{UO}_{2(\mathrm{~s})}+1 / 2 \mathrm{~S}_{8}{ }^{0}(\mathrm{~s})+3 \mathrm{OH}^{-}+4 \mathrm{H}_{2} \mathrm{O}(2)
$$

$$
\left(\mathrm{UO}_{2}\right)_{3}(\mathrm{OH})_{5}{ }^{+}+3 \mathrm{HS}^{-} \rightarrow 3 \mathrm{UO}_{2(\mathrm{~s})}+3 / 8 \mathrm{~S}_{8}{ }^{0}(\mathrm{~s})+2 \mathrm{OH}^{-}+3 \mathrm{H}_{2} \mathrm{O}(3)
$$


1 are in good agreement with the reported ranges for synthetic, biogenic, and hydrothermal

2 uraninite specimens (Schofield et al., 2008; Sharp et al., 2009; Singer et al., 2009). The distinct

3 second shell feature at 3.81-3.82 $\AA$ originating from the strong backscattering by U neighbors

4 excludes possibilities of molecular U(IV) monomers recently reported for microbial U(VI)

5 reduction (Bernier-Latmani et al., 2010; Fletcher et al., 2010; Sivawamy et al., 2011). These

6 EXAFS structural parameters suggest precipitation of uraninite in the homogeneous reaction of

7 U(VI) with aqueous sulfide under circum-neutral $\mathrm{pH}$ in the presence of $\mathrm{Ca}^{2+}$ and CARB.

$9 \quad$ 3.2. Factors Affecting U(VI) Reduction Kinetics.

3.2.1. $U(V I)$ concentration. When the initial $\mathrm{U}(\mathrm{VI})$ concentration was $5.5 \times 10^{-5} \mathrm{M}$, U

11 reduction was clearly observed at $\mathrm{pH} 7$ in the reaction with $1 \mathrm{mM}$ dissolved $\mathrm{S}(-\mathrm{II})$ in the presence

12 of $1 \mathrm{mM} \mathrm{CARB}$ and $5 \mathrm{mM} \mathrm{Ca}^{2+}$ concentrations (Fig. 5a). When the initial U(VI) concentration

13 was lowered to $3.5 \times 10^{-7} \mathrm{M}$, U reduction was much slower under the same experimental 14 conditions (Fig. 5b). At 5mM CARB, the rate of $\mathrm{U}$ removal from solution was much slower for 15 both initial $\mathrm{U}$ concentrations (Fig. 5a and 5b). The carbonate effect is discussed below in more 16 detail.

17

3.2.2. Dissolved $S(-I I)$. Presented in Fig. 5c are the results for U(VI) reactions with

19 different aqueous sulfide concentrations as a function of time without added $\mathrm{Ca}^{2+}$. The rate of $\mathrm{U}$ 20 removal from solution was faster at higher dissolved sulfide concentration. When the dissolved 21 sulfide concentration was $10 \mathrm{mM}$, the dissolved $\mathrm{U}$ concentration decreased to below detection 22 within half an hour. The dissolved U concentration had a gentler slope and was below detection 23 after $\sim 2 \mathrm{~h}$ of reaction when reacted with $1 \mathrm{mM} \mathrm{S}(-\mathrm{II})$. 
3.2.3. $\mathrm{Ca}^{2+}$ Concentration. Increasing $\mathrm{Ca}^{2+}$ concentration slowed the $\mathrm{U}(\mathrm{VI})$ removal

3 rate from solution (Fig. 5d). When the dissolved $\mathrm{Ca}^{2+}$ concentration was $0.3 \mathrm{mM}$, dissolved $\mathrm{U}$

4 concentration decreased to below detection within $2 \mathrm{~h}$ from the start of the reaction, whereas it

5 took $10 \mathrm{~h}$ to reach below detection when the $\mathrm{Ca}^{2+}$ concentration was increased to $5 \mathrm{mM}$.

6

3.2.4. CARB Concentration. The CARBconcentration effect observed in Fig. 5 in

8 conjunction with the U(VI) concentration was studied in more detail in the presence of $5 \mathrm{mM}$

$9 \mathrm{Ca}^{2+}$ (Fig. 6). The initial total carbonate concentration was varied between 1 and 5mM. A rapid

10 decrease in dissolved $U$ concentration occurred under the $1 \mathrm{mM}$ CARB condition, but the

11 reduction and disappearance of dissolved $\mathrm{U}$ was slowed as the CARB concentration increased to

12 1.5, 2.0, and 3.0mM (Fig. 6). Virtually no reduction was observed when the CARB concentration

13 was raised to $5.0 \mathrm{mM}$ (Fig. 6). This is an important observation given that $5.0 \mathrm{mM}$ and higher

14 CARB concentrations are commonly observed in groundwaters, including the Rifle aquifer

15 (Hyun et al., 2009; Fox et al., 2012).

16

\subsection{U(VI) Reaction with Sulfide in Synthetic Rifle Groundwater.}

The typical $\mathrm{pH}$ range of the Rifle groundwater is between 6.62 and 7.42 with the mean value of 6.94 (US DOE, 1999), suggesting that abiotic U reduction by aqueous sulfide could be

20 feasible at the Rifle site if other conditions (e.g. $\mathrm{Ca}^{2+}$ and CARB concentrations) are favorable.

21 The results of abiotic $U$ reduction by aqueous sulfide in a synthetic groundwater sample are

22 shown in Fig. 7. A slow decrease in the dissolved $U$ concentration was observed as a function of 23 time under the initial U(VI) concentrations of $4 \times 10^{-5}, 4 \times 10^{-6}$, and $4 \times 10^{-7} \mathrm{M}$. A $1^{\text {st }}$ order reduction 
1 rate was obtained using the decrease in dissolved $U$ concentration as a function of time. This

2 rate was extrapolated to estimate dissolved U(VI) concentrations after two and three weeks to

3 compare with the observed $U$ concentration variation in field biostimulation experiments

4 (Yabusaki et al., 2007). The extrapolation suggests that $86 \%$ and $95 \%$ of the initial U(VI) would

5 be reduced after two and three weeks, respectively. This estimated concentration decrease is less

6 than what was observed during the Fe(III)-reducing phase of the biostimulation experiments

7 carried out at the Rifle site (Yabusaki, 2007), although a straightforward, direct comparison is

8 difficult due to differences in geochemical, flow, and mixing conditions. After the initial 50 days

9 of acetate injection, rapid U removal was observed in the field experiment, along with an

10 increase in dissolved $\mathrm{Fe}(\mathrm{II})$ concentration in the groundwater. Sulfate reduction followed

11 between 50 and 100 days after the start of acetate injection, but during this phase of the

12 experiment, the dissolved $U$ concentration slightly increased. The increase in dissolved U

13 concentration may have occurred because of slow U(VI) desorption processes from the

14 sediments that were greater in magnitude than $U$ reduction by sulfate reducers (Williams et al.,

15 2011). Our results suggest that abiotic U(VI) reduction by aqueous sulfide may also contribute

16 to the various processes that influence dissolved $\mathrm{U}(\mathrm{VI})$ concentrations under sulfate reducing

17 conditions, although the net result is apparent increase in dissolved U concentration.

\section{4. Discussion}

$\mathrm{U}(\mathrm{VI})$ was reduced to $\mathrm{U}(\mathrm{IV})$ by reaction with aqueous sulfide under certain combinations

22 of experimental conditions. In general, higher S(-II), higher U(VI), circumneutral pH, lower

$23 \mathrm{CARB}$, and lower $\mathrm{Ca}^{2+}$ concentrations provided favorable conditions for abiotic $\mathrm{U}$ reduction by

24 aqueous sulfide. At $\mathrm{pH} \mathrm{7,} \mathrm{the} \mathrm{products} \mathrm{of} \mathrm{the} \mathrm{electron} \mathrm{transfer} \mathrm{reaction} \mathrm{between} \mathrm{aqueous} \mathrm{sulfide}$ 
1 (major species $\mathrm{HS}^{-}$) and $\mathrm{U}(\mathrm{VI})$ were elemental sulfur and uraninite in the $\mathrm{Ca}^{2+}$ - and CARB-free

2 system as evidenced by X-ray diffraction (XRD), X-ray absorption spectroscopy (XAS), and

3 transmission electron microscopy (TEM: Figure 2). XAS confirmed that the solid phases formed

4 in the $\mathrm{Ca}^{2+}$ - and CARB-added systems were also uraninite (Figures 3 and 4). This is consistent

5 with the results of Hua et al. (2006), although these authors used different experimental

6 conditions, e.g., use of $\mathrm{pH}$ buffers and higher CARB concentrations and the absence of $\mathrm{Ca}^{2+}$.

$7 \quad$ Thermodynamic calculations show systematic changes in U(VI) aqueous speciation as

8 functions of the above mentioned experimental variables. U(VI) reduction rate was dependent on

9 the solution variables, suggesting U(VI) speciation-dependent reduction. The overall reduction

10 can be written with reactions involving the two major U(VI) aqueous species under the

11 experimental conditions studied (Table S1):

$$
\mathrm{Ca}_{2} \mathrm{UO}_{2}\left(\mathrm{CO}_{3}\right)_{3(\mathrm{aq})}+\mathrm{HS}^{-}=\mathrm{UO}_{2(\mathrm{~s})}+1 / 8 \mathrm{~S}_{8}{ }^{0}(\mathrm{~s})+2 \mathrm{Ca}^{2+}+2 \mathrm{CO}_{3}{ }^{2-}+\mathrm{HCO}_{3}^{-}
$$

$$
\mathrm{CaUO}_{2}\left(\mathrm{CO}_{3}\right)_{3}{ }^{2-}+\mathrm{HS}^{-}=\mathrm{UO}_{2(\mathrm{~s})}+1 / 8 \mathrm{~S}_{8}{ }^{0}(\mathrm{~s})+\mathrm{Ca}^{2+}+2 \mathrm{CO}_{3}{ }^{2-}+\mathrm{HCO}_{3}{ }^{-}
$$

14 However, no direct quantitative kinetic relation between the concentrations of the dominant $\mathrm{U}(\mathrm{VI})$ aqueous species and observed U(VI) reduction rates can be drawn from the experimental 16 data in this case. The observed dependency of the reduction rate on each experimental variable 17 suggests that the reduction takes a path composed of a set of parallel elementary steps involving 18 minor U(VI) species, and thus depends on solution variables that affect their concentrations. EXAFS characterization shows that $\mathrm{Ca}_{2} \mathrm{UO}_{2}\left(\mathrm{CO}_{3}\right)_{3(\mathrm{aq})}$ has the local structure of a central $20 \mathrm{U}(\mathrm{VI})$ atom with two axial oxygen atoms at $1.78 \AA$ as in free uranyl ion $\left(\mathrm{UO}_{2}{ }^{2+}\right)(\mathrm{Kelley}$ et al., 21 2007). This species also has six equatorial oxygen atoms at $2.45 \AA$, shared with three carbon 22 atoms of the carbonate neighbors located at $2.90 \AA$ from the central uranium atom, and two $\mathrm{Ca}^{2+}$ 23 atoms at $4.01 \AA$ (Brooks et al., 2003). The kinetic results of this study suggest that its structure is 
1 stable in water and resistant to reduction by dissolved sulfide, compared to the free uranyl ion

2 and its hydrolysis complexes. It leads to the conclusion that its filled coordination structure

3 hinders electron transfer between bisulfide ion and the central U(VI), making it an unfavorable

$4 \mathrm{U}(\mathrm{VI})$ species for reduction by aqueous S(-II). However, the concentration of this species did not

5 show a direct relationship with $\mathrm{U}(\mathrm{VI})$ reduction rate under the experimental conditions

6 investigated, given the rate of reduction of this species is much slower. Instead, the U(VI)

7 reduction rate was proportional to the concentration of $\mathrm{U}(\mathrm{VI})$ species with more favorable

8 structures for reduction, such as the free uranyl and its hydroxide complexes. Therefore, the

9 impact of the soluble Ca-U(VI)-CARB species on the abiotic reduction of U(VI) species by

10 sulfide is related to the extent to which the formation of the calcium complex lowers the

11 equilibrium concentration of U(VI)-hydroxide species (Supplementary data). Those

12 groundwater conditions that increase the initial concentration of the more reactive U(VI)

13 hydroxyl species will tend to enhance the rate of dissolved U(VI) abiotic reduction by dissolved 14 sulfide.

Standard and conditional half-cell potentials for possible major U(VI) aqueous species 16 are given in Table S2 (in Supplementary data). For example, at $4 \times 10^{-5} \mathrm{M} \mathrm{U}(\mathrm{VI}), 5 \mathrm{mM} \mathrm{Ca}{ }^{2+}$, $175 \mathrm{mM}$ total carbonate, and $\mathrm{pH} 7$, the half-cell potential values indicate that $\mathrm{Ca}_{2} \mathrm{UO}_{2}\left(\mathrm{CO}_{3}\right)_{3(\mathrm{aq})}$ has 18 the least favorable and the uranyl ion the most favorable free energy for reduction to uraninite. 19 The conditional half-cell potential values at $\mathrm{pH} 7$ show that $4 \times 10^{-7} \mathrm{M} \mathrm{U}(\mathrm{VI}), 5 \mathrm{mM} \mathrm{Ca}{ }^{2+}$, and $205 \mathrm{mM}$ total carbonate are the least favorable set of conditions for $\mathrm{Ca}_{2} \mathrm{UO}_{2}\left(\mathrm{CO}_{3}\right)_{3(\mathrm{aq})}$ reduction to 21 uraninite of those investigated here. The rate trends observed in this study in which higher $22 \mathrm{U}(\mathrm{VI})$, lower $\mathrm{Ca}$, and lower CARB concentration lead to faster U(VI) reduction by sulfide are 23 consistent with the thermodynamic favorability of reduction. 

of U(VI) in the presence of carbonate and calcium, Brooks et al. (2003) reported that calcium caused a significant decrease in bacterial U(VI) reduction by Schewanella putrefaciens strain

4 CN32, Desulfovibrio desulfuricans, and Geobacter sulfurreducens. Ulrich et al. (2011) studied the relationship between $\mathrm{U}(\mathrm{VI})$ bioreduction kinetics and $\mathrm{U}(\mathrm{VI})$ aqueous speciation. They too reported systematic correlations between the rate constant, Gibbs free energy of reaction, and Eh in the bioreduction of $\mathrm{U}(\mathrm{VI})$ by Shewanella onedensis strain MR-1, with the reduction rate

8 increasing with conditions that favored overall free energy of reduction. They reported the 9 fastest reduction with U(VI)-hydroxyl and U(VI)-organic species, slower reduction of the U(VI)carbonate group, and much slower reduction of the $\mathrm{Ca}-\mathrm{U}(\mathrm{VI})$-carbonate group. These trends are

11 also supportive of our results, even though they investigated rates of microbiological processes; they did not consider abiotic reduction of $\mathrm{U}(\mathrm{VI})$ as a possible pathway. reduction by sulfide. As mentioned earlier, Hua et al. (2006) reported the inhibition of dissolved carbonate on abiotic U(VI) reduction by dissolved sulfide through the formation of uranyl 16 carbonate complexes, but did not consider $\mathrm{Ca}^{2+}$ impacts. In the absence of $\mathrm{Ca}^{2+}$, they concluded 17 that U(VI)-hydroxyl species were favorably and relatively rapidly reduced by sulfide, in contrast 18 to the dominant $\mathrm{U}(\mathrm{VI})$-carbonate species. By including $\mathrm{Ca}^{2+}$, we have extended the range of conditions to those more representative of groundwater, and the potentially even more significant 20 inhibition by $\mathrm{Ca}^{2+}$.

22 more than $99 \%$ of the total dissolved U(VI) present in the Ca and carbonate added systems 23 (Table S1), with the relative abundance of each being dependent on U(VI), $\mathrm{Ca}^{2+}$, and CARB 
1 concentrations and $\mathrm{pH}$. The calculations also show that the concentrations of uranyl hydroxide

2 species have dependency on the same variables. For instance, free $\mathrm{UO}_{2}{ }^{2+}$ is $5.90 \times 10^{-11} \mathrm{M}$ and

$34.84 \times 10^{-13} \mathrm{M}$ under $1 \mathrm{mM}$ and $5 \mathrm{mM}$ total carbonate conditions, respectively. The sum of free

4 uranyl and uranyl-hydroxide species is $4.91 \times 10^{-9} \mathrm{M}$ at $1 \mathrm{mM}$ total carbonate compared with

$5 \quad 3.72 \times 10^{-11} \mathrm{M}$ at $5 \mathrm{mM}$ carbonate.

6 The thermodynamic considerations show that $\mathrm{Ca}_{2} \mathrm{UO}_{2}\left(\mathrm{CO}_{3}\right)_{3(\mathrm{aq})}$ is the most abundant but

7 the least favorable $\mathrm{U}(\mathrm{VI})$ aqueous species to be reduced by aqueous sulfide in our experimental

8 systems. It is not practical to determine the reduction rate for individual U(VI) species due to the

9 complexity of U(VI) aqueous chemistry under the experimental conditions considered (See

10 Supplementary data). Nonetheless, it is instructive to establish an empirical relation, although

11 not strictly derivable from elementary reaction steps, from the data we have obtained. Assuming

12 the reaction order of 0.54 for $\mathrm{HS}^{-}$as in Hua et al. (2006), the following empirical relation fits the

13 abiotic $\mathrm{U}(\mathrm{VI})$ reduction rate data by aqueous sulfide under the conditions with $\mathrm{S}(-\mathrm{II})=1 \mathrm{mM}$ and

$14 \mathrm{Ca}^{2+}=5 \mathrm{mM}$ :

15

$$
-\frac{\mathrm{d}[\mathrm{U}(\mathrm{VI})]}{\mathrm{dt}}=3 \times 10^{-11}\{\Sigma[\mathrm{CARB}]\}^{-3.402}[U(V I)]_{\text {Tot }}\left[H S^{-}\right]^{0.54}
$$

where $\Sigma[\mathrm{CARB}]$ is the sum of all the dissolved carbonate species and $[\mathrm{U}(\mathrm{VI})]_{\mathrm{Tot}}$ is the total

17 dissolved $\mathrm{U}(\mathrm{VI})$ concentration. $\mathrm{U}(\mathrm{VI})$ reduction rate has a strong dependency on CARB concentration, which in turn has a systematic negative correlation with the sum of the 19 equilibrium concentrations of free uranyl and its hydroxyl complexes, a similar tendency observed by Hua et al. (2006) for their Ca-free model systems. The above empirical relation well

21 explains the observation that the rate of abiotic $\mathrm{U}(\mathrm{VI})$ reduction by aqueous sulfide is dependent

22 on the concentrations of free uranyl and uranyl hydrolysis complexes, even though they are 23 minor or trace species under the experimental conditions (Fig. 8). 
A comparison with Hua et al. (2006)'s rate constants determined in Ca-free systems was

2 made to illustrate the suspected importance of the $\mathrm{Ca}^{2+}-\mathrm{UO}_{2}$-carbonate species in slowing the

3 kinetics of $\mathrm{U}(\mathrm{VI})$ reduction by aqueous sulfide. The reduction of $\mathrm{U}(\mathrm{VI})$ in $\mathrm{Ca}_{2} \mathrm{UO}_{2}\left(\mathrm{CO}_{3}\right)_{3(\mathrm{aq})}$ or

$4 \mathrm{CaUO}_{2}\left(\mathrm{CO}_{3}\right)_{3}{ }^{2-}$ estimated by this approach is significantly slower than U(VI) reduction observed

5 for U(VI)-carbonate complexes, consistent with the conclusion of Brooks et al. (2003). The

6 extrapolation of the empirical relation of this study $\left(k=3 \times 10^{-11}[\Sigma \mathrm{CARB}]^{-3.402}\right)$ gives the

7 reduction rate constant $k$ value of $0.0043\left[\mathrm{~mol} \cdot \mathrm{L}^{-1} \cdot \mathrm{s}^{-1}\right]$ for $4 \mathrm{mM} \mathrm{CARB}$ condition used by Hua et

8 al. (2006), along with $[\mathrm{U}(\mathrm{VI})]=168.3 \mu \mathrm{M},\left[\mathrm{HS}^{-}\right]=1 \mathrm{mM}$, and $\mathrm{pH}=6.89$. This value is about $40 \%$ of

9 the value reported by Hua et al. (2006), i.e., $k$ of $0.0103\left[\mathrm{~mol} \cdot \mathrm{L}^{-1} \cdot \mathrm{s}^{-1}\right]$ in their kinetic equation

$10 \quad\left(-\frac{\mathrm{d}[\mathrm{U}(\mathrm{VI})]}{\mathrm{dt}}=0.0103[\mathrm{U}(\mathrm{VI})]\left[\mathrm{S}^{2-}\right]_{\mathrm{T}}^{0.54}\right)$ obtained under $\mathrm{Ca}^{2+}$-free conditions. This comparison

11 supports the implied importance of $\mathrm{Ca}-\mathrm{U}(\mathrm{VI})$-carbonate species in slowing $\mathrm{U}(\mathrm{VI})$ reduction by

12 aqueous sulfide.

\section{Summary and Conclusions}

The results of this study show that abiotic reduction of U(VI) to uraninite by aqueous sulfide can occur to a significant extent under certain sets of chemical conditions. Under higher

$17 \mathrm{U}(\mathrm{VI})$, higher $\mathrm{S}(-\mathrm{II})$, lower $\mathrm{CARB}$, and lower $\mathrm{Ca}^{2+}$ conditions, rapid $\mathrm{U}(\mathrm{VI})$ reduction was observed at $\mathrm{pH}$ 7. If $\mathrm{U}(\mathrm{VI})$ is present in higher concentrations of free uranyl or its hydrolysis complexes, abiotic $\mathrm{U}(\mathrm{VI})$ reduction by aqueous sulfide is accelerated. However, at the $5 \mathrm{mM}$ CARB and $4 \times 10^{-7} \mathrm{M}$ dissolved $\mathrm{U}(\mathrm{VI})$ concentrations, which are within the typical range of the

21 Rifle groundwater system, significant U reduction was not observed within 48h, but could 22 contribute to $\mathrm{U}$ reduction over a longer period of time. The dominance of $\mathrm{Ca}-\mathrm{U}(\mathrm{VI})$-carbonate 23 soluble complexes and their stability in water slow abiotic reduction by S(-II). Thus, 
1 groundwater geochemical variables can have significant impacts on the abiotic U reduction rate

2 by changing $\mathrm{U}(\mathrm{VI})$ aqueous speciation. The findings of this study suggest that abiotic reduction

3 by aqueous sulfide is an important process to consider in assessing $\mathrm{U}$ redox chemistry under

4 sulfate reducing conditions achieved either naturally or by biostimulation, and this process needs

5 to be considered in developing field-scale $\mathrm{U}$ reactive transport models.

6 In conclusion, this study reports the reaction of $\mathrm{U}(\mathrm{VI})$ with aqueous sulfide under a range

7 of experimental conditions including $\mathrm{pH}$, dissolved $\mathrm{U}(\mathrm{VI}), \mathrm{Ca}^{2+}$, and $\mathrm{CARB}$ concentrations. The

8 following results are found in this study:

$9 \quad-\mathrm{U}(\mathrm{VI})$ is abiotically reduced to uraninite by aqueous sulfide under certain combinations

\section{Acknowledgment}

This research was funded by the U.S. Department of Energy (DOE) Office of Science, Environmental Remediation Sciences Program (ERSP) via two projects "The Integrated Fieldscale Subsurface Research Challenge (IFRC) Site at Rifle, Colorado, USA" and "Assessing the Role of Iron Sulfides in the Long Term Sequestration of Uranium by Sulfate-Reducing Bacteria," and in part by KIGAM's Basic Research Project (14-3218). Portions of this research were carried out at the Stanford Synchrotron Radiation Lightsource, a Directorate of SLAC National Accelerator Laboratory and an Office of Science User Facility operated for the U.S. Department of Energy Office of Science by Stanford University. The SSRL Structural Molecular Biology 
1 Program is supported by the DOE Office of Biological and Environmental Research, and by the

2 National Institutes of Health, National Center for Research Resources, Biomedical Technology

3 Program (P41RR001209).

4

\section{$5 \quad$ References}

6 Anderson, R.T.; Vrionis, H.A.; Ortiz-Bernad, I.; Resch, C.T.; Long, P.E.; Dayvault, R.; Karp, K.;

7 Marutzky, S.; Metzler, D.R.; Peacock, A.; White, D.C.; Lowe, M.; Lovley, D.R. Stimulating the in situ activity of Geobacter species to remove uranium from the groundwater of a uranium-contaminated aquifer. Appl. Environ. Microb. 2003, 69, 5884-5891.

Ankudinov, A.; Ravel, B.; Rehr, J.J. FEFF8, The FEFF Project, Department of Physics, University of Washington, 2002.

12 Bargar, J.R.; Reitmeyer, R.; Lenhart, J.J.; Davis, J.A. Characterization of U(VI)-carbonato ternary complexes on hematite: EXAFS and electrophoretic mobility measurements. Geochim. Cosmochim. Acta 2000, 64, 2737-2749. 
Borch, T.; Kretzschmar, R.; Kappler, A.; van Cappellen, P.; Ginder-Vogel, M.; Voegelin, A.; Campbell, K. Biogeochemical redox processes and their impact on contaminant dynamics. Environ. Sci. Technol. 2010, 44, 15-23.

Brooks, S. C.; Fredrickson, J. K.; Carroll, S. L.; Kennedy, D. W.; Zachara, J. M.; Plymale, A. E.; Kelly, S. D.; Kemner, K. M.; Fendorf, S. Inhibition of bacterial U(VI) reduction by calcium. Environ. Sci. Technol. 2003, 37, 1850-1858.

Chakraborty, S.; Favre, F.; Banerjee, D.; Scheinost, A. C.; Mullet, M.; Ehrhardt, J. -J.; Brendle, J.; Vidal, L.; Charlet, L. U(VI) sorption and reduction by Fe(II) sorbed on montmorillonite. Environ. Sci. Technol. 2010, 44, 3779-3785.

Dong, W.; Brooks, S. C. Determination of the formation constants of ternary complexes of uranyl and carbonate with alkaline earth metals $\left(\mathrm{Mg}^{2+}, \mathrm{Ca}^{2+}, \mathrm{Sr}^{2+}\right.$, and $\left.\mathrm{Ba}^{2+}\right)$ using anion exchange method. Environ. Sci. Technol. 2006, 40. 4689-4695.

Fletcher, K.E.; Boyanov, M.I.; Thomas, S.H.; Wu, Q.; Kemner, K.M.; Loffler, F.E. U(VI) reduction to mononuclear U(IV) by Desulfitobacterium species. Environ. Sci. Technol. 2010, 44, 4705-4709.

Fox, P. M.; Davis, J. A.; Hay, M. B.; Conrad, M. E.; Campbell, K. M.; Williams, K. H.; Long, P. E., Rate-limited U(VI) desorption during a small-scale tracer test in a heterogeneous uranium contaminated aquifer, Water Resour. Res. 2012, 48, W05512, doi:10.1029/2011WR011472.

Fox, P.M., Davis, J.A., Kukkadapu, R., Singer, D.M., Bargar, J.R., and Williams, K.H., Abiotic $\mathrm{U}(\mathrm{VI})$ reduction by sorbed Fe(II) on natural sediments, Geochim. Cosmochim. Acta 2013, $117,266-282$. 
1 Ginder-Vogel, M.; Criddle, C.S.; Fendorf, S. Thermodynamic constraints on the oxidation of 2 biogenic $\mathrm{UO}_{2}$ by Fe(III) (hydr)oxides. Environ. Sci. Technol. 2006, 40, 3544-3550.

3 Guillaumont, R.; Fanghanel, T.; Furger, J.; Grenthe, I.; Neck, V.; Palmer, D. A.; Rand, M. H. 4 Update on the Chemical Thermodynamics of Uranium, Neptunium, Plutonium, Americium, 5 and Technetium; Elsevier: Amsterdam, 2003.

6 Hua, B.; Deng, B. Reductive immobilization of uranium(VI) by amorphous iron sulfide. Environ. $7 \quad$ Sci. Technol. 2008, 42, 8703-8708.

8 Hua, B.; Xu, H.; Terry, J.; Deng, B. Kinetics of uranium(VI) reduction by hydrogen sulfide in $9 \quad$ anoxic aqueous systems. Enviorn. Sci. Technol. 2006, 40, 4666-4671.

Hyun, S. P.; Davis, J. A.; Sun, K.; Hayes, K. F. Uranium(VI) reduction by iron(II) monosulfide mackinawite. Environ. Sci. Technol. 2012, 46, 3369-3376.

Hyun, S. P.; Fox, P. M.; Davis, J. A.; Campbell, K. M.; Hayes, K. F.; Long, P. E. Surface complexation modeling of $\mathrm{U}(\mathrm{VI})$ adsorption by aquifer sediments from a former mill tailings sites at Rifle, Colorado. Environ. Sci. Technol. 2009, 43, 9368-9373.

Jeon, B. -H.; Dempsey, B. A.; Burgos, W. D.; Barnett, M. O.; Roden, E. E. Chemical reduction of $\mathrm{U}(\mathrm{VI})$ by $\mathrm{Fe}(\mathrm{II})$ at the solid-water interface using natural and synthetic $\mathrm{Fe}(\mathrm{III})$ oxides. Environ. Sci. Technol. 2005, 39, 5642-5649.

Kelley, S.; Kemner, K. M.; Brooks, S. C. X-ray absorption spectroscopy identifies calciumuranyl-carbonate complexes at environmental concentrations. Geochim. Cosmochim. Acta 2007, 71, 821-834.

Liger, E.; Charlet, L.; van Cappelen, P. Surface catalysis of uranium(VI) reduction by iron(II). Geochim. Cosmochim. Acta 1999, 63, 2939-2955. 
Livens, F. R.; Jones, M. J.; Hynes, A. J.; Charnock, J. M.; Mosselmans, J. F. W.; Hennig, C.; Steele, H.; Collison, D.; Vaughan, D. J.; Pattrick, R. A. D.; Reed, W. A.; Moyes, L. N. X-ray absorption spectroscopy studies of reactions of technetium, uranium, and neptunium with mackinawite. J. Environ. Radioactiv. 2004, 74, 211-219.

Lovley, D. R.; Phillips, E. J. P. Reduction of uranium by Desulfovibrio desulfuricans. Appl. Environ. Microb. 1992, 58, 850-856.

Lovley, D. R., Roden, E. E., Phillips, E. J. P.; Woodward, J. C. Enzymatic iron and uranium reduction by sulfate-reducing bacteria. Mar Geol. 1993, 113, 41-53.

Mereiter, K. The crystal structure of Liebigite, $\mathrm{Ca}_{2} \mathrm{UO}_{2}\left(\mathrm{CO}_{3}\right)_{3} \cdot 11 \mathrm{H}_{2} \mathrm{O}$. Tschermarks Min. Petr. Mitt. 1982, 30, 277-288.

Moon, H.S.; McGuinness, L.; Kukkadapu, R.K.; Peacock, A.D.; Komlos, J.; Kerkhof, L.J.; Long, P.E.; Jaffe, P.R. Microbial reduction of uranium under iron- and sulfate-reducing conditions: Effect of amended goethite on microbial community composition and dynamics. Water Research 2010, 44, 4015-4028.

Moyes, L.N.; Parkman, R.H.; Charnock, J.M.; Vaughan, D.J.; Livens, F.R.; Hughes, C.R.; Braithwaite, A. Uranium uptake from aqueous solution by interaction with goethite, lepidocrocite, muscovite, and mackinawite: An X-ray absorption spectroscopy study. Environ. Sci. Technol. 2000, 34, 1062-1068.

O’Loughlin, E. J.; Kelly, S. D.; Cook, R. E.; Csencsits, R.; Kemner, K. M. Reduction of uranium(VI) by mixed iron(II)/iron(III) hydroxide (green rust): Formation of $\mathrm{UO}_{2}$ nanoparticles. Environ. Sci. Technol. 2003, 37, 721-727.

Pietzsch, K; Hard, B. C.; Babel, W. A Desulfovibrio sp. capable of growing by reducing U(VI). J. Basic Microbiol. 1999, 39, 365-372. 
Qafoku, N.P.; Kukkadapu, R.K.; McKinley, J.P.; Arey, B.W.; Kelly, S.D. Wang, C; Resch, C.T.; Long, P.E. Uranium in framboidal pyrite from a naturally bioreduced alluvial sediment. Environ. Sci. Technol. 2009, 43, 8528-8534.

Ravel, B. ATOMS: Crystallography for the X-ray absorption spectroscopist. J. Synchrotron Radiat. 2001, 8, 314-316.

Reeder, R. J.; Nugent, M.; Tait, C. D., Morris, D. E.; Heald, S. M.; Beck, K. M.; Hess, W. P.; Lanzirotti, A. Coprecipitation of uranium(VI) with calcite: XAFS, micro-XAS, and luminescence characterization. Geochim. Cosmochim. Acta 2001, 65, 3491-3503.

Rosenspurg, S.; Schild, D.; Schafer, T.; Huber, F.; Malmstrom, M. E. Removal of uranium(VI) from the aqueous phase by iron(II) minerals in presence of bicarbonate. Appl. Geochem. 2009, 24, 1617-1625.

Schofield, E.J.; Veeramani, H.; Sharp, J.O.; Suvorova, E.; Bernier-Latmani, R.; Mehta, A.; Stahlman, J.; Webb, S.M.; Clark, D.L.; Conradson, S.D.; Ilton, E.S.; Bargar, J.R. Structure of biogenic uraninite produced by Shewanella oneidensis strain MR-1. Environ. Sci. Technol. 2008, 42, 7898-7904.

Sharp, J.O.; Schofield, E.J.; Veeramani, H.; Suvorova, E.I.; Kennedy, D.W.; Marshall, M.J.; Mehta, A.; Bargar, J.R.; Bernier-Latmani, R. Structural similarities between biogenic uraninites produced by phylogenetically and metabolically diverse bacteria. Environ. Sci. Technol. 2009, 43, 8295-8301.

Singer, D.M.; Farges, F.; Brown, Jr., G.E. Biogenic nanoparticulate $\mathrm{UO}_{2}$ : Synthesis, characterization, and factors affecting surface reactivity. Geochim. Cosmochim. Acta 2009, 73, 3593-3611. 
Sivawamy, V.; Boyanov, M.I.; Peyton, B.M.; Viamajala, S.; Gerlach, R.; Apel, W.A.; Sani, R.K.; Dohnalkova, A.; Kemner, K.M.; Borch, T. Multiple mechanisms of uranium immobilization by Celluomonas sp. strain ES6. Biotechnol. Bioeng. 2011, 108, 264-276.

Ulrich, K.-U.; Veeramani, H.; Bernier-Latmani, R.; Giammar, D. E. Speciation-dependent kinetics of uranium(VI) bioreduction. Geomicrobiol. J. 2011, 28, 396-409.

Final site observational workplan for the UMTRA project Old Rifle site; U.S. Department of Energy Grand Junction Office: Grand Junction, Colorado, 1999.

Webb, S.M. Sam's Interface for XAS Package (SixPACK). Stanford Synchrotron Radiation Laboratory, 2002.

Wersin, P.; Hochella, Jr., M.F.; Persson, P.; Redden, G.; Leckie, J.O.; Harris, D.W. Interaction between aqueous uranium(VI) and sulfide minerals: Spectroscopic evidence for sorption and reduction. Geochim. Cosmochim. Acta 1994, 58, 2829-2843.

Williams, K. H.; Long, P. E.; Davis, J. A.; Wilkins, M. J.; N'Guessan, A. L.; Steefel, C. I.; Yang, L.; Newcomer, D.; Spane, F. A.; Kerkhof, L. J.; McGuinness, L.; Dayvault, R.; Lovley, D. R. Acetate availability and its influence on sustainable bioremediation of uraniumcontaminated groundwater. Geomicrobiol. J. 2011, 28, 519-539.

Wyckoff, R.W. G. Crystal Structures. John Wiley \& Sons, New York, 1978.

Yabusaki, S. B.; Fang, Y.; Long, P. E.; Resch, C. T.; Peacock, A. D.; Komlos, J.; Jaffe, P. R.; Morrison, S. J.; Dayvault, R. D.; White, D. C.; Anderson, R. T. Uranium removal from groundwater via in situ biostimulation: Field-scale modeling of transport and biological processes. J. Contam. Hydrol., 2007, 93, 216-235. 
1 Table 1. Structural parameters extracted from the EXAFS analysis ( $N$ : coordination number of 2 backscatterer atoms around the absorber $\mathrm{U}$ atom, $R$ : interatomic distance (in $\AA$ ) of the absorber3 backscatterer pair, $\sigma^{2}$ : Debye-Waller factor (in $\AA^{2}$ )of the absorber-backscatterer pair. The $4 \quad$ subscript stands for the kind of backscatterer). ${ }^{a}$ : $U(V I)$ samples reacted with aqueous sulfide at $5 \quad \mathrm{CARB}=1 \mathrm{mM}, \mathrm{Ca}^{2+}=5 \mathrm{mM}, \mathrm{S}(-\mathrm{II})=1 \mathrm{mM}$, and $\mathrm{U}(\mathrm{VI})=0.1 \mathrm{mM}$ under circum-neutral but slightly 6 different $\mathrm{pH}$ conditions.

\begin{tabular}{|c|c|c|c|c|c|c|c|c|c|c|}
\hline \multicolumn{2}{|c|}{ Shell } & $\mathrm{pH} 7.3^{\mathrm{a}}$ & $\mathrm{pH} 7.1^{\mathrm{a}}$ & $\mathrm{pH} 6.7^{\mathrm{a}}$ & $\begin{array}{c}\text { U_Stock } \\
\text { (1000 } \\
\text { ppm } \\
\text { uranyl } \\
\text { solution) }\end{array}$ & $\begin{array}{c}\text { Uraninite } \\
\text { (Wyckoff, } \\
\text { 1978) } \\
\text { From } \\
\text { XRD }\end{array}$ & $\begin{array}{l}\text { Uraninite } \\
\text { Synthetic } \\
\text { (Hyun et } \\
\text { al., 2012) }\end{array}$ & $\begin{array}{c}\text { Uraninite } \\
\text { Biogenic } \\
\text { (Hyun et } \\
\text { al., 2012) }\end{array}$ & $\begin{array}{c}\mathrm{UO}_{2.00(\mathrm{~s})} \\
\text { Synthetic } \\
\text { (Schofield } \\
\text { et al., } \\
\text { 2008) }\end{array}$ & $\begin{array}{c}\text { Uraninite } \\
\text { Biogenic } \\
\text { (Schofield } \\
\text { et al., } \\
\text { 2008) }\end{array}$ \\
\hline \multirow[t]{3}{*}{$\mathrm{O}$} & $N$ & $5.8(8)$ & $6.5(0)$ & $6.1(4)$ & & 8 & $6.5(5)$ & $7.2(8)$ & 8 & 8 \\
\hline & $R$ & $2.32(3)$ & $2.33(0)$ & $2.32(5)$ & & 2.3678 & $2.25(5)$ & $2.33(4)$ & $2.354(7)$ & $2.347(7)$ \\
\hline & $\sigma^{2}$ & 0.0105 & 0.0109 & 0.0098 & & 0 & 0.0164 & 0.0122 & $0.0046(7)$ & $0.0103(6)$ \\
\hline \multirow[t]{3}{*}{$\mathrm{U}^{\mathrm{IV}}$} & $N$ & $5.3(8)$ & $5.4(5)$ & $5.3(4)$ & & 12 & $2.5(2)$ & $4.8(8)$ & 12 & $6(1)$ \\
\hline & $R$ & $3.81(0)$ & $3.81(9)$ & $3.81(8)$ & & 3.8666 & $3.84(4)$ & $3.83(7)$ & $3.867(4)$ & $3.846(5)$ \\
\hline & & 0.0079 & 0.0069 & 0.0062 & & 0 & 0.0071 & 0.0105 & 0.0029 & $0.0055(7)$ \\
\hline \multirow[t]{3}{*}{$\mathrm{O}_{\mathrm{ax}}$} & $N$ & & & & $2.4(5)$ & & & & & \\
\hline & $R$ & & & & $1.77(0)$ & & & & & \\
\hline & ${ }_{2}^{\square} \sigma$ & & & & 0.0030 & & & & & \\
\hline \multirow[t]{3}{*}{$\mathrm{O}_{\mathrm{eq}}$} & $N$ & & & & $4.8(3)$ & & & & & \\
\hline & $R$ & & & & $2.42(3)$ & & & & & \\
\hline & ${ }_{2}^{\square} \sigma$ & & & & 0.0061 & & & & & \\
\hline \multirow[t]{3}{*}{$\mathrm{C}$} & $N$ & & & & & & & & & \\
\hline & $R$ & & & & & & & & & \\
\hline & ${ }_{2}^{\square} \sigma$ & & & & & & & & & \\
\hline $\begin{array}{l}\mathrm{R}- \\
\text { factor }\end{array}$ & & 0.0762 & 0.0787 & 0.0527 & & & & & & \\
\hline
\end{tabular}


3 Figure 1. Dissolved U concentration as a function of time in the reaction of $180 \mu \mathrm{M} U(\mathrm{VI})$ with

$4 \quad 1 \mathrm{mM} \mathrm{S}(-\mathrm{II})$ in the model system without $\mathrm{Ca}^{2+}$ and CARB. The first region is at $\mathrm{pH} 10.7$ and the 5 second is at $\mathrm{pH} 7$.

6

7 Figure 2. U solid phase precipitated at $\mathrm{pH} 7$ in the $\mathrm{Ca}^{2+}$ - and CARB-free simple model system.

8 (a) X-ray diffraction pattern, (b) high resolution transmission electron micrograph showing the

9 lattice fringe image, (c) selected area electron diffraction pattern, (d) U $L_{\mathrm{III}}$ edge X-ray

10 absorption near edge structure with the inflection point at $17172 \mathrm{eV}$, and (e) extended X-ray

11 absorption fine structure spectrum (left) and corresponding Fourier transform magnitude function

12 (right: circles (data) and solid line (fit)). The precipitate is uraninite.

14 Figure 3. The $1^{\text {st }}$ derivative $U L_{\mathrm{III}}$ edge XANES spectra of solid samples precipitated under 15 different $\mathrm{pH}$ conditions in the $\mathrm{Ca}^{2+}$ and $\mathrm{CARB}$ added systems along with those of the U(VI) 16 solution and synthetic uraninite model compounds $(\mathrm{CARB}=1 \mathrm{mM}, \mathrm{Ca}=5 \mathrm{mM}, \mathrm{S}=1 \mathrm{mM}$, and $17 \mathrm{U}=0.1 \mathrm{mM})$.

Figure 4. U $L_{\mathrm{III}}$ edge EXAFS spectra and the corresponding Fourier transform magnitude 20 functions of the solids precipitated under different $\mathrm{pH}$ conditions. A) U(VI) solution model 21 compound (without $\mathrm{Ca}^{2+}$ and CARB), Solid precipitated in the $\mathrm{Ca}^{2+}$ and $\mathrm{CARB}$ added systems $22\left(\mathrm{CARB}=1 \mathrm{mM}, \mathrm{Ca}^{2+}=5 \mathrm{mM}, \mathrm{S}(-\mathrm{II})=1 \mathrm{mM}\right.$, and $\left.\mathrm{U}(\mathrm{VI})=0.1 \mathrm{mM}\right)$ at B) $\mathrm{pH}$ 6.7, C) 7.1, D) 7.3, and E) 23 uraninite model compound (Hyun et al., 2012; circles: data, solid lines: fits). 
1 Figure 5. Effects of geochemical variables on the U(VI) reduction kinetics by aqueous sulfide.

2 a) Initial $\mathrm{U}(\mathrm{VI})=5.5 \times 10^{-5} \mathrm{M}, \mathrm{pH} 7, \mathrm{Ca}^{2+}=5 \mathrm{mM}, \mathrm{HS}^{-}=1 \mathrm{mM}$, b) Initial $\mathrm{U}(\mathrm{VI})=3.5 \times 10^{-7} \mathrm{M}, \mathrm{pH} 7$,

$\left.3 \mathrm{Ca}^{2+}=5 \mathrm{mM}, \mathrm{HS}^{-}=1 \mathrm{mM}, \mathrm{c}\right)$ Initial $\mathrm{U}(\mathrm{VI})=1.9 \times 10^{-4} \mathrm{M}, \mathrm{pH} 7, \mathrm{CARB}=1 \mathrm{mM}$, no $\mathrm{Ca}^{2+}$ added, and

4 d) Initial $\mathrm{U}(\mathrm{VI})=5 \times 10^{-5} \mathrm{M}, \mathrm{pH}, \mathrm{CARB}=1 \mathrm{mM}, \mathrm{HS}^{-}=1 \mathrm{mM}$.

5

6 Figure 6. Changes in dissolved U(VI) concentration as a function of time in the reaction of U(VI)

7 with $\mathrm{HS}^{-}$under different $\mathrm{CARB}$ concentration conditions: Initial $\mathrm{U}(\mathrm{VI})=4 \times 10^{-5} \mathrm{M}, \mathrm{Ca}^{2+}=5 \mathrm{mM}$,

$8 \mathrm{HS}^{-}=1 \mathrm{mM}$, and $\mathrm{pH} 7$.

9

10 Figure 7. U(VI) reduction kinetics by aqueous sulfide in an artificial groundwater solution

$11 \quad\left(\mathrm{Na}^{+}=10 \mathrm{mM}, \mathrm{K}^{+}=0.4 \mathrm{mM}, \mathrm{Mg}^{2+}=4 \mathrm{mM}, \mathrm{Ca}^{2+}=4.8 \mathrm{mM}, \mathrm{HCO}_{3}^{-}=7.7 \mathrm{mM}, \mathrm{Cl}^{-}=3 \mathrm{mM}, \mathrm{SO}_{4}{ }^{2-}=8.8 \mathrm{mM}\right.$, 12 and $\mathrm{pH}=7)$.

13

14 Figure 8. Comparison of U(VI) reduction rate constants $(k)$ as a function of CARB concentration 15 with aqueous $\mathrm{U}(\mathrm{VI})$ speciation: (A) $\Sigma\left(\mathrm{U}^{\mathrm{VI}}-\mathrm{OH}\right),(\mathrm{B}) \Sigma\left(\mathrm{U}^{\mathrm{VI}}-\mathrm{CARB}\right)$, and (C) $\Sigma\left(\mathrm{Ca}-\mathrm{U}^{\mathrm{VI}}-\mathrm{CARB}\right)$. 16

17 
1 Fig. 1

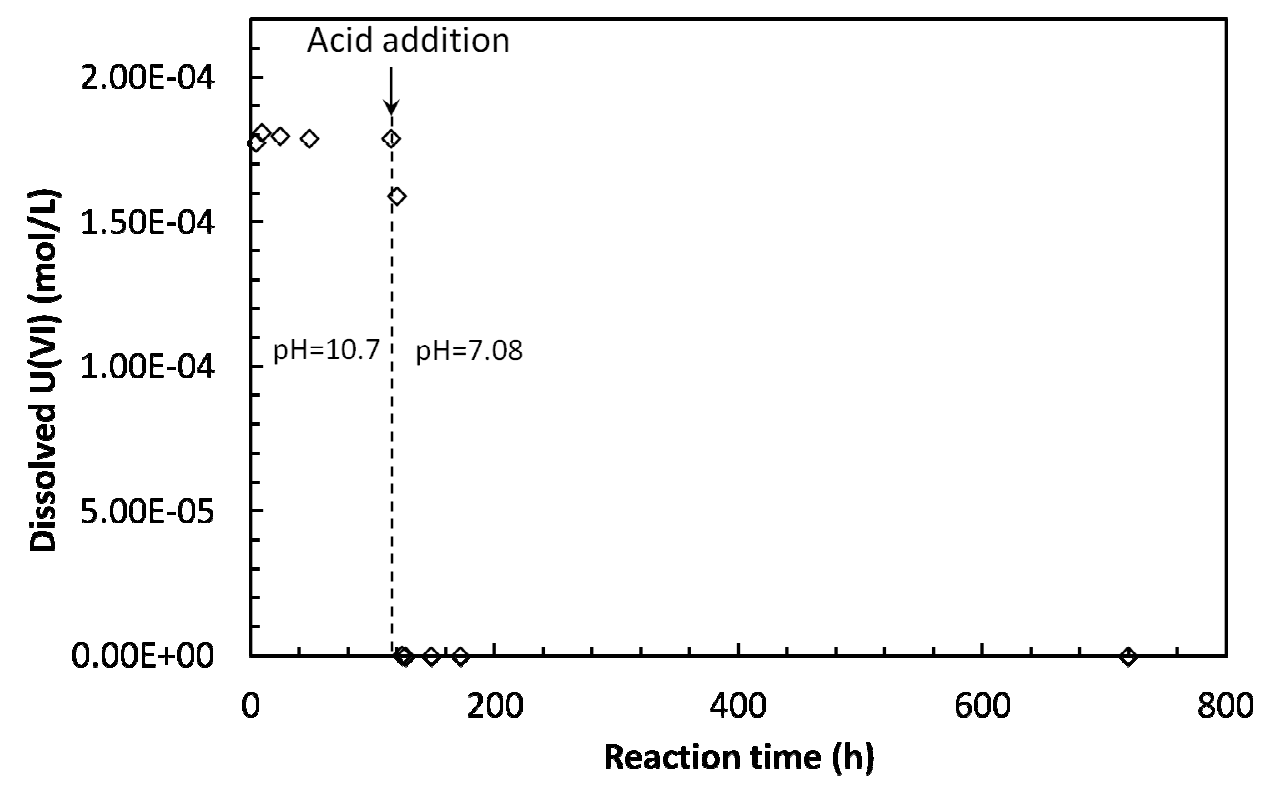



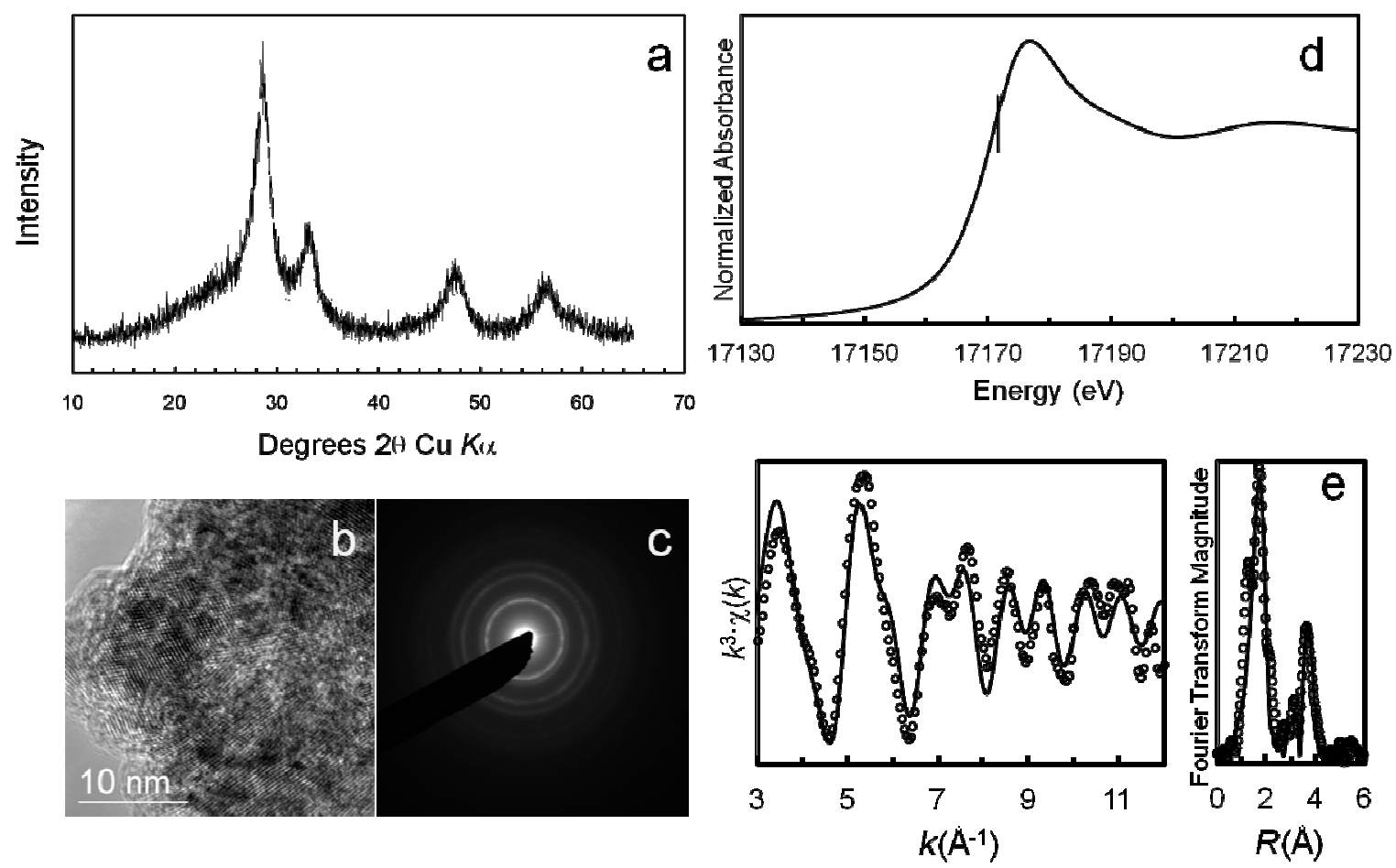
Fig. 3

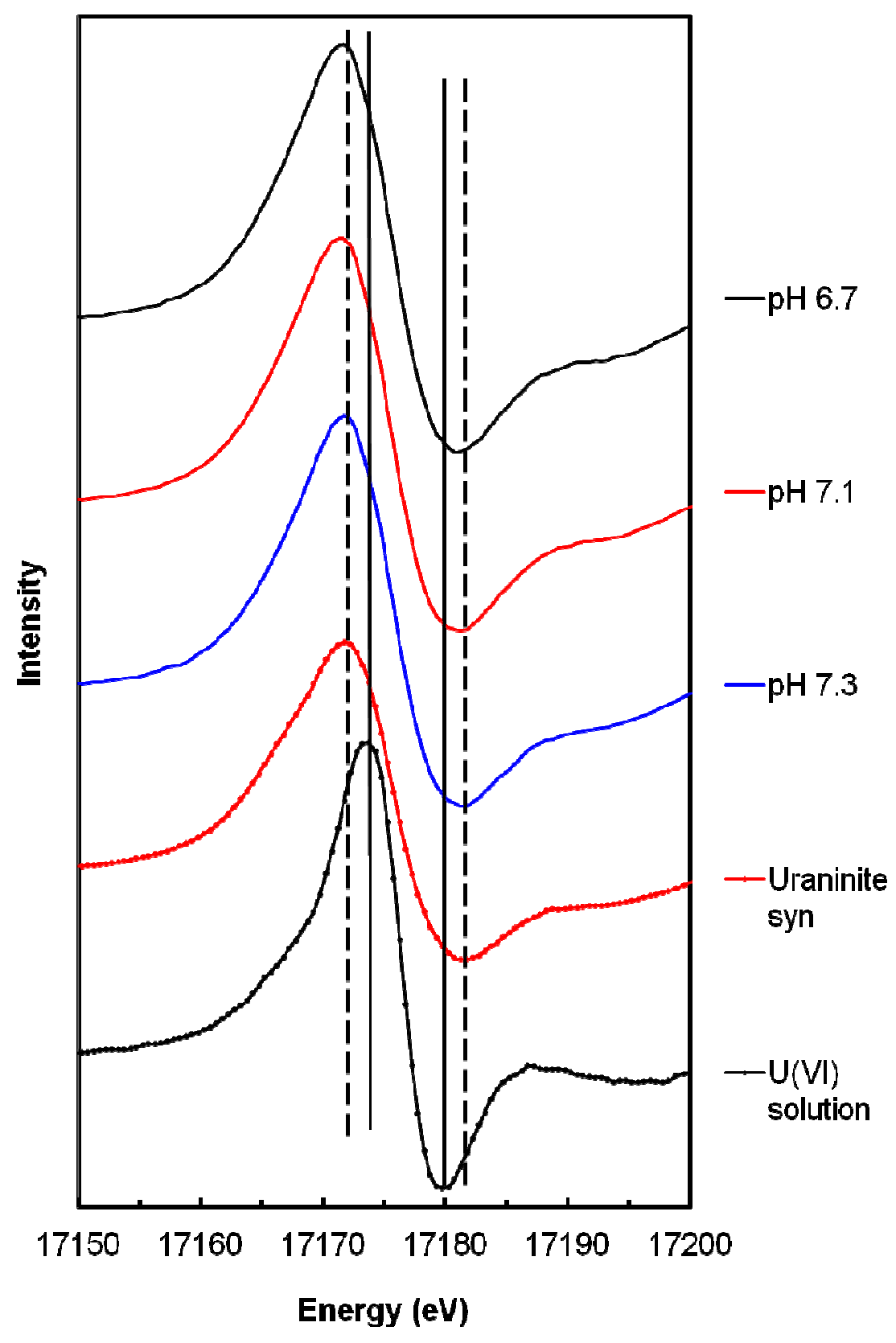


Fig. 4

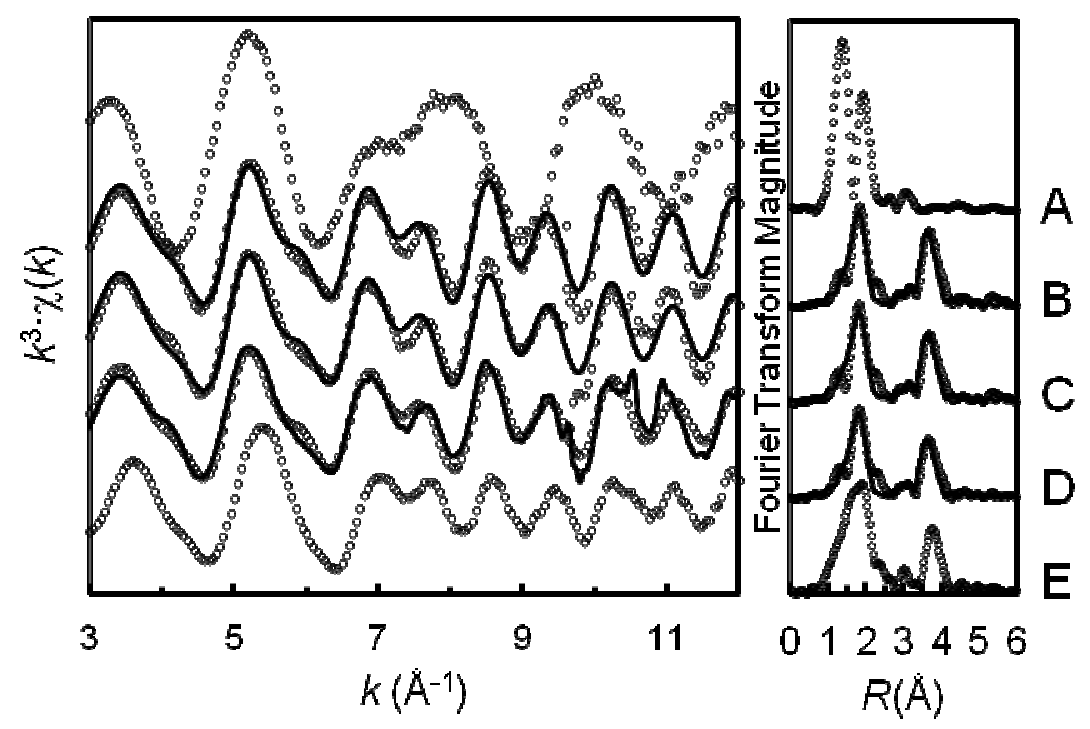


1 Fig. 5

2
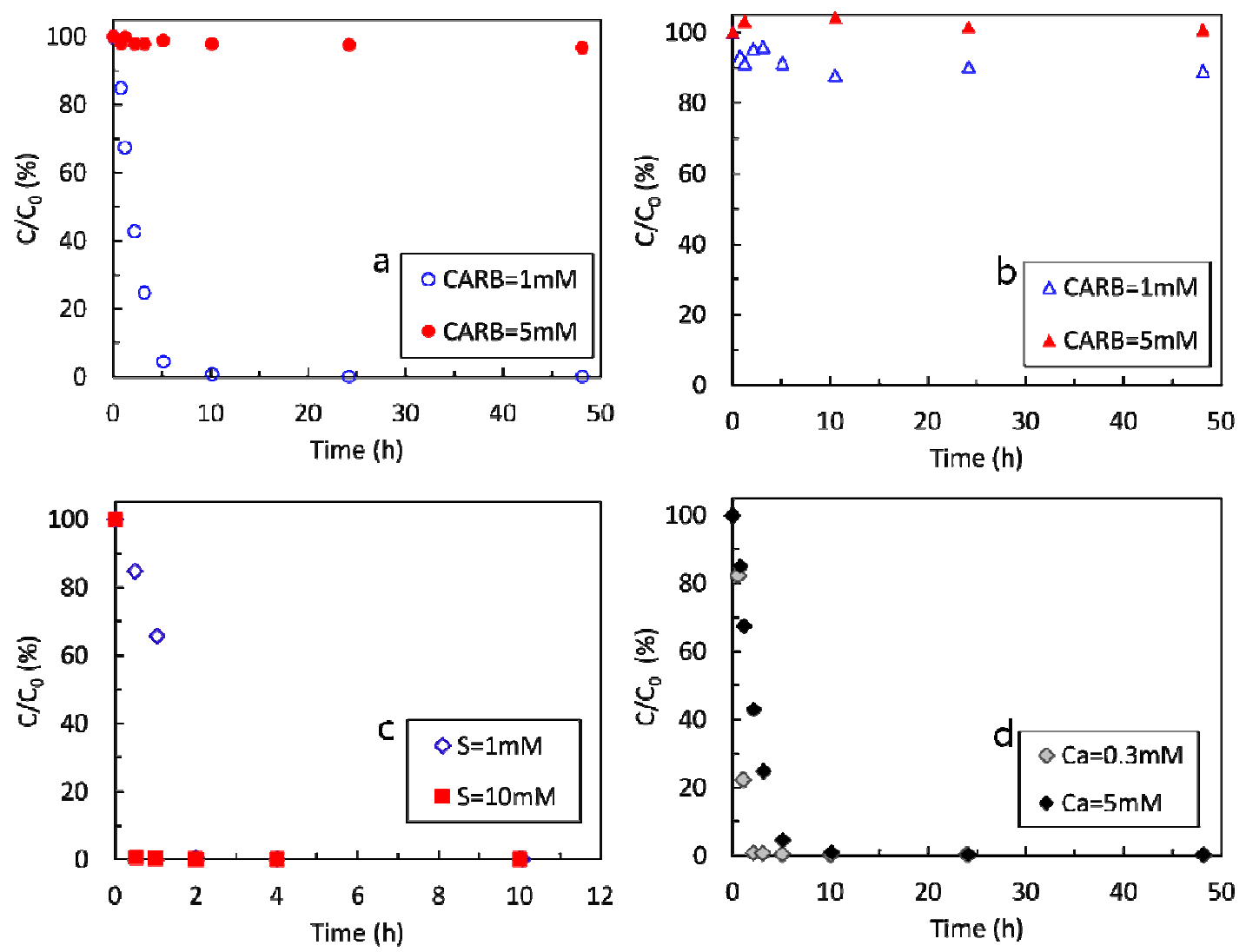

3 
1 Fig. 6

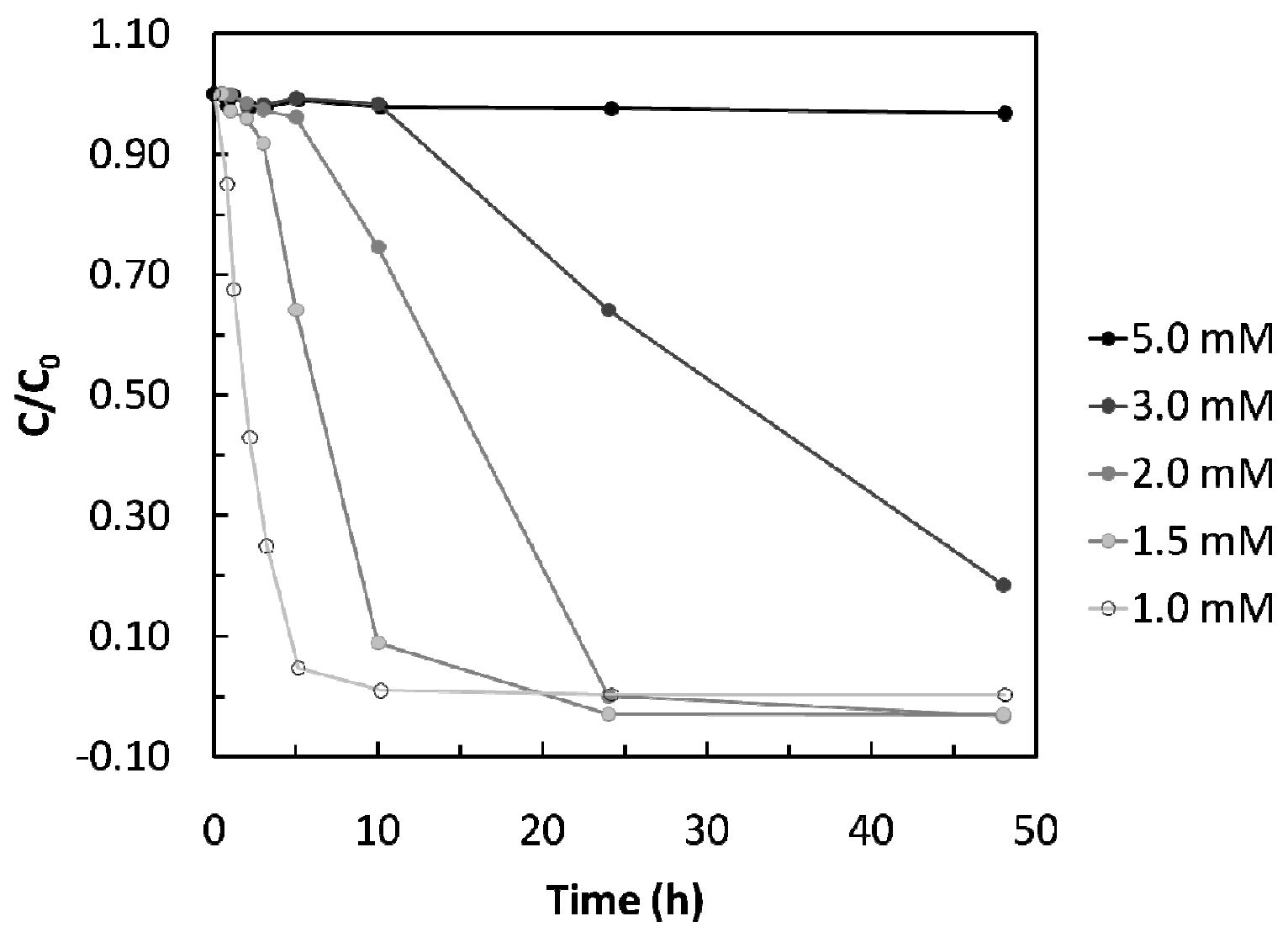

2 
1 Fig. 7

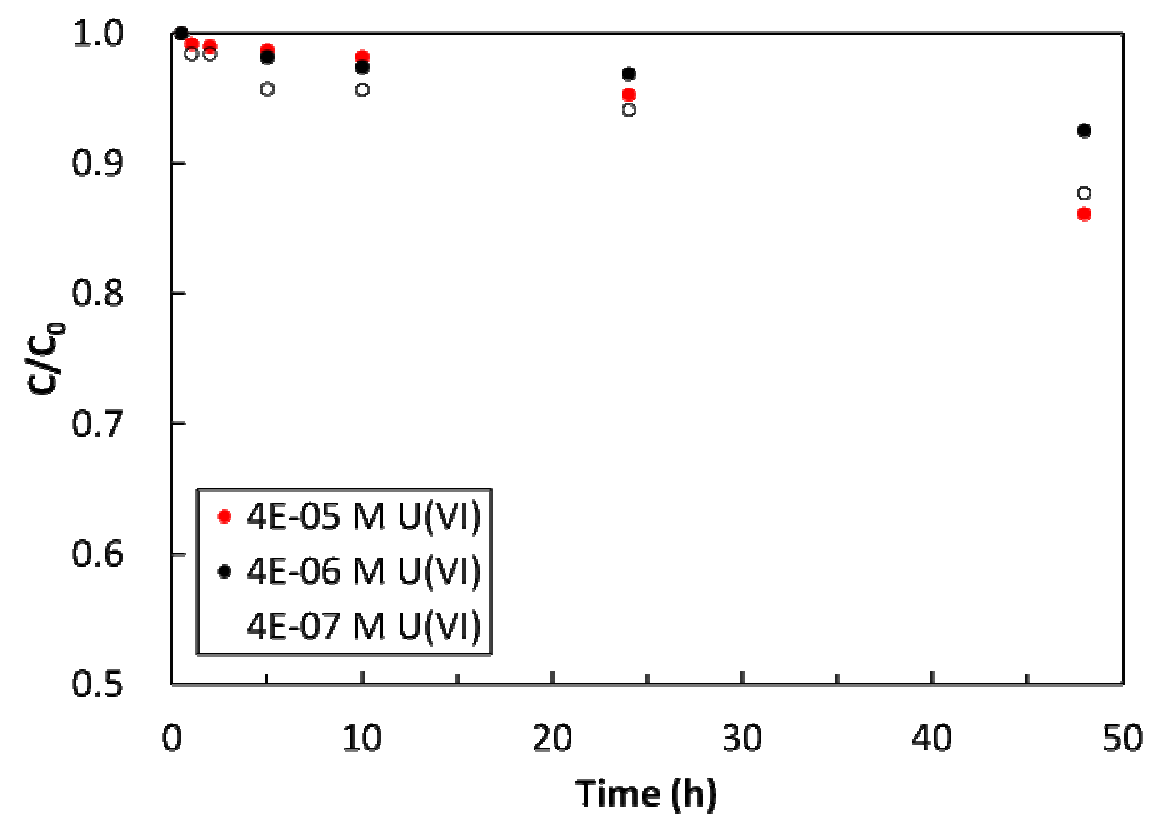

2 
Fig. 8
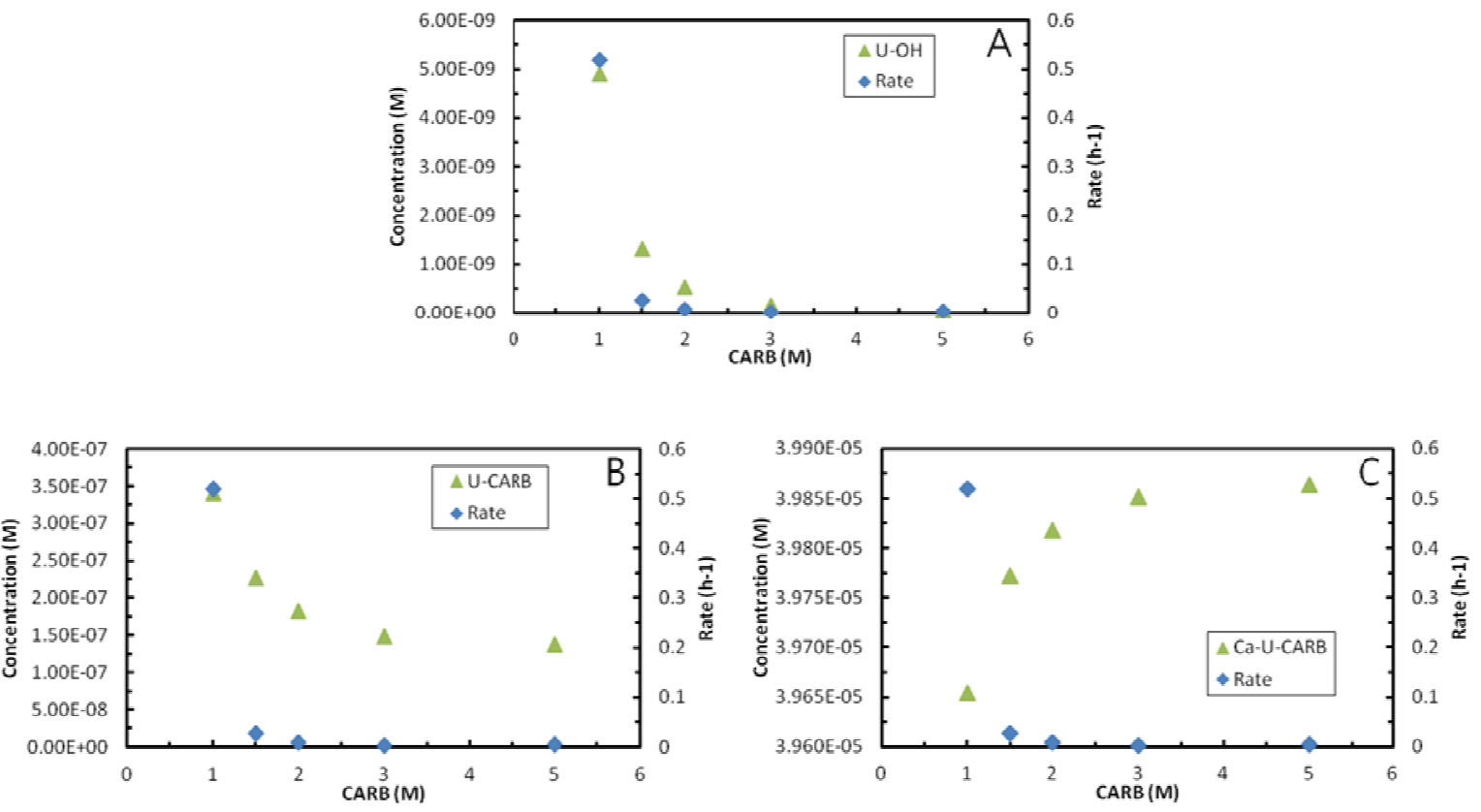